\title{
Letter \\ Co-incidental increase in gene copy number of ERBB2 and LRIG1 in breast cancer
}

\author{
Ingrid Ljuslinder ${ }^{1}$, Irina Golovleva ${ }^{2}$, Roger Henriksson ${ }^{1}$, Kjell Grankvist $^{3}$, Beatrice Malmer ${ }^{1}$ \\ and Håkan Hedman ${ }^{1}$
}

\begin{abstract}
1'Department of Radiation Sciences, Oncology, Umeå University Hospital, SE-90187, Umeå, Sweden ${ }^{2}$ Department of Medical Biosciences, Medical and Clinical Genetics, SE-90187, Umeå, Sweden

${ }^{3}$ Department of Medical Biosciences, Clinical Chemistry, Umeå University, SE-90187, Umeå, Sweden

${ }^{4}$ Department of Pathology, Umeå University, SE-90187, Umeå, Sweden
\end{abstract}

Corresponding author: Ingrid Ljuslinder, ingrid.ljuslinder@onkologi.umu.se

Published: 12 May 2009

This article is online at http://breast-cancer-research.com/content/11/3/403

Breast Cancer Research 2009, 11:403 (doi:10.1186/bcr2248)

(c) 2009 BioMed Central Ltd

See related research article by Ljuslinder et al., http://breast-cancer-research.com/content/7/5/R719

Using fluorescence in situ hybridization (FISH), we previously showed that the $L R / G 1$ gene had an increased copy number in 11 of $28(39 \%)$ breast cancer tumours [1]. The LR/G1 gene (leucine-rich repeats and immunoglobulin-like domains 1 ) at chromosome $3 p 14$ is a proposed tumour suppressor gene that negatively regulates various receptor tyrosine kinases, including the breast cancer proto-oncogene product ERBB2 $[2,3]$.

Recently, however, Miller and colleagues [4] showed that 10 of $13(76 \%)$ ERBB2 ${ }^{+}$tumours had decreased LRIG1 protein levels compared to normal breast tissue. As their data showed down-regulation at the protein level whereas our data showed an increased copy number at the genomic level, we analysed 45 additional breast tumours by FISH as previously described [1]. Thus, out of 73 tumours analysed to date, 25 (34\%) did indeed have increased LRIG1 copy number. To further analyse the relationship between $L R / G 1$ and $E R B B 2$ at the genomic level, we evaluated the ERBB2 gene copy numbers in 18 tumours with increased LRIG1 copy number using FISH analysis according to standard procedures. Interestingly, 16 (89\%) out of the 18 tumours displayed increased copy number of ERBB2 (Figure 1). This suggests that the majority of breast cancer tumours with increased copy number of ERBB2 simultaneously had increased $L R I G 1$ copy number (our data) and decreased LRIG1 protein levels [4].

We draw the following major conclusions from these results. First, as previously shown, a significant proportion of breast tumours have an increased LR/G1 gene dosage. Second, there is a correlation between increased gene copy numbers
Figure 1

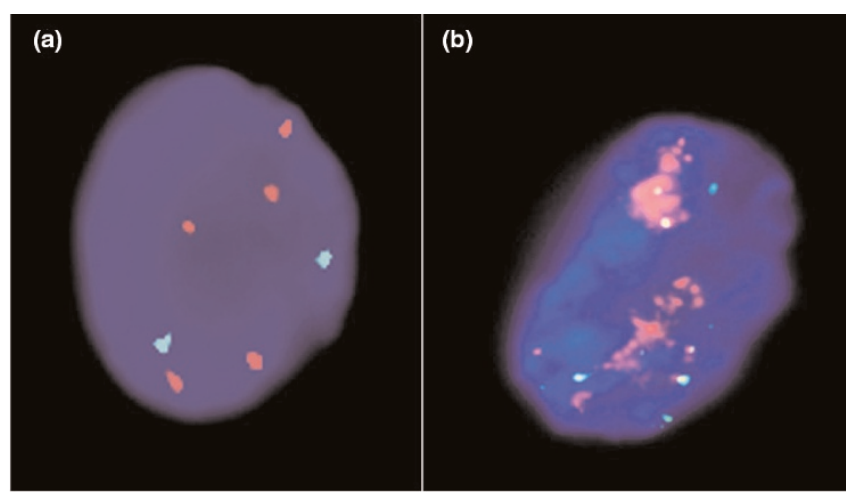

Increased copy number of $L R / G 1$ and $E R B B 2$ in human breast cancer in the same patient. Interphase nuclei from a breast cancer tumour were analysed by FISH. (a) A specific $L R I G 1$ probe (red) showed increased $L R / G 1$ copy number (five copies) whereas a specific centromere probe (CEP3) (green) showed normal chromosome 3 copy number (two copies). (b) A specific ERBB2 probe (red) showed amplification of the ERBB2 gene whereas a specific centromere probe (CEP17; green) showed three copies of chromosomes 17.

of ERBB2 and LRIG1. Third, based on the Miller protein data, most of the tumours with increased $L R I G 1$ gene dosage express reduced levels of the LRIG1 protein. This indicates a negative selection against LRIG1 protein expression, supporting the notion that $L R / G 1$ is a tumour suppressor in breast cancer. Although the mechanism behind the down-regulation of LRIG1 protein in breast cancer is not known, it has been reported that increased gene copy

$\mathrm{FISH}=$ fluorescence in situ hybridization. 
numbers in some cases are associated with decreased mRNA expression [5]. In any case, the high frequency (34\%) of tumours with increased LR/G1 gene copy number implies a positive selection for tumour cells with this genomic alteration. It remains, however, to be elucidated whether the molecular driver behind the selective advantage associated with this alteration is LRIG1 down-regulation per se. Other possibilities include activation of nearby proto-oncogenes or the generation of novel oncogenic fusion genes.

In summary, the co-incidental increase in copy number of $E R B B 2$ and $L R I G 1$ in breast cancer is a novel finding, pointing at a functional co-operation between these genetic events, where the biological and clinical importance need to be clarified further.

\section{Competing interests}

The authors declare that they have no competing interests.

\section{References}

1. Ljuslinder I, Malmer B, Golovleva I, Thomasson M, Grankvist K, Hockenstrom T, Emdin S, Jonsson Y, Hedman H, Henriksson R: Increased copy number at $3 \mathrm{p} 14$ in breast cancer. Breast Cancer Res 2005, 7:R719-727.

2. Gur G, Rubin C, Katz M, Amit I, Citri A, Nilsson J, Amariglio N, Henriksson R, Rechavi G, Hedman H, Wides R, Yarden Y: LRIG1 restricts growth factor signaling by enhancing receptor ubiquitylation and degradation. EMBO J 2004, 23:3270-3281.

3. Laederich MB, Funes-Duran M, Yen L, Ingalla E, Wu X, Carraway $\mathrm{KL}$ 3rd, Sweeney C: The leucine-rich repeat protein LRIG1 is a negative regulator of ErbB family receptor tyrosine kinases. J Biol Chem 2004, 279:47050-47056.

4. Miller JK, Shattuck DL, Ingalla EQ, Yen L, Borowsky AD, Young LJ, Cardiff RD, Carraway KL 3rd, Sweeney C: Suppression of the negative regulator LRIG1 contributes to ErbB2 overexpression in breast cancer. Cancer Res 2008, 68:8286-8294.

5. Stranger BE, Forrest MS, Dunning M, Ingle CE, Beazley C, Thorne N, Redon R, Bird CP, de Grassi A, Lee C, Tyler-Smith C, Carter N, Scherer SW, Tavaré S, Deloukas P, Hurles ME, Dermitzakis ET: Relative impact of nucleotide and copy number variation on gene expression phenotypes. Science 2007, 315:848-853. 